\title{
A Case of Granulomatous Mastitis due to Corynebacterium amycolatum
}

\author{
Corynebacterium amycolatum'un Neden OIduğu Granülomatöz Mastit Olgusu
}

\author{
(1) Zeynep BAHADIR ${ }^{1}$, (1) Nur Banu KALKAN ${ }^{2}$, (1) Mesut YILMAZ ${ }^{3}$ \\ 1istanbul Medipol University Faculty of Medicine, Istanbul, Turkey \\ 2istanbul Tuzla State Hospital, istanbul, Turkey \\ 3istanbul Medipol University Faculty of Medicine, Department of Infectious Diseases and Clinical Microbiology, istanbul, Turkey
}

\section{Abstract}

Mastitis is a generalized cellulitis condition of breast tissue usually seen in female patients between 18-50 years of age. Granulomatous mastitis $(\mathrm{GM})$, which is one of the rare types, is usually an idiopathic disease and can be caused by infectious microorganisms. In this report, a 35-year-old female patient diagnosed as having GM infected with Corynebacterium amycolatum was reported and the relevant literature was reviewed. The patient was treated with a combination of amoxicillin/clavulanic acid and clindamycin and no recurrence was observed at 10 months follow-up. Keywords: Corynebacterium, Corynebacterium amycolatum, mastitis, granulomatous mastitis, MALDI-TOF MS

\section{Öz}

Mastit, genellikle 18-50 yaşlarındaki kadın hastalarda görülen meme dokusunun yaygın selülit durumudur. Nadir tiplerinden biri olan granülomatöz mastit (GM) ise genellikle idiyopatik bir hastalık olup, enfeksiyöz nedenlerle de oluşabilir. Bu olgu raporunda Corynebacterium amycolatum ile enfekte GM tanısı almış 35 yaşında kadın hasta bildirilmiş ve ilgili literatür bilgileri gözden geçirilmiştir. Hasta amoksisilin/klavulanik asit ve klindamisin kombinasyonu ile tedavi edilmiş, hastanın 10 aylık takibinde nüks saptanmamıştır.

Anahtar Kelimeler: Corynebacterium, Corynebacterium amycolatum, mastit, granülomatöz mastit, MALDI-TOF MS

\section{Introduction}

Granulomatous mastitis (GM) refers to a rare chronic benign inflammatory disease of the breast. It is an important clinical condition of which etiology includes infectious and noninfectious processes, which can mimic malignancy clinically and radiologically, and which may cause panic in the diagnostic process $^{[1,2]}$.

The disease usually progresses with a unilateral breast mass in young women of childbearing age. Tuberculosis (most commonly
Mycobacterium tuberculosis), sarcoidosis, fungal infections, as well as autoimmune diseases such as Wegener's granulomatosis and giant cell arteritis may be the leading inflammatory etiologies of $\mathrm{GM}^{[2]}$. These conditions are clinically, pathologically or radiologically similar and cannot be distinguished from idiopathic $\mathrm{GM}^{[3]}$.

Recently, it has been reported that the frequency of isolation of Corynebacterium species in patients diagnosed as having GM is gradually increasing. There are no published treatment protocols in the literature for Corynebacterium-associated 
breast infections ${ }^{[4]}$. In this report, a patient with GM caused by Corynebacterium amycolatum who was admitted to our outpatient clinic with complaints of breast pain, mass and discharge, and was successfully treated with a combination of oral antibiotics was presented.

\section{Case Report}

A 35-year-old married woman with three children was admitted with complaints of pain, redness and swelling in the right breast. It was learned that the patient's complaints that started two months ago were accompanied by chills and shivering fever, especially at night. There was no history of travel, animal contact, trauma and oral contraceptive use in the period before the patient's complaints started. The patient, who weaned her three-year-old child eight months ago, stated that she had a slight swelling in her right breast at that time, but the swelling went away on its own after a while.

In physical examination; her general condition was good, tympanic fever was $37{ }^{\circ} \mathrm{C}$, her pulse rate was $80 /$ minute, her respiratory rate was $12 /$ minute, and her arterial blood pressure was $110 / 75 \mathrm{mmHg}$. Inspection and palpation revealed 3 reddened and discharged lesions in the upper outer quadrant of her right breast and lymphadenopathies in the axillary region.

In laboratory examinations; hematocrit was 37\%, hemoglobin was $12.8 \mathrm{~g} / \mathrm{dl}$, white blood cell count was 12000/mm³ $(64.2 \%$ neutrophils), platelet count was $419.000 /$ ul, C-reactive protein level was $2.7 \mathrm{mg} / \mathrm{dl}$, and all other biochemical indicators were within normal limits.

In her anamnesis, it was learned that the ultrasound and mammography findings of the patient who was first admitted to the general surgery outpatient clinic were found to be suspicious for inflammatory malignancy, that a trucut biopsy was performed from the upper outer quadrant of the right breast, and that the result was reported to be consistent with $\mathrm{GM}$ with active chronic inflammation, inflammatory response accompanied by granulomas without necrosis, and microabscess formations. Empirical ciprofloxacin treatment was initiated in the patient and she was admitted to our outpatient clinic because there was no improvement for one month. Tissue samples were taken from the patient's lesions with biopsy. Uniform and dense Corynebacterium genus Gram-positive rods were produced in aerobic tissue culture and defined as Corynebacterium amycolatum with matrix-assisted laser desorption/ionization time-of-flight mass spectrometry (MALDI-TOF MS) (VITEK ${ }^{\circledast}$ MS, Biomérieux, France). Antibiotic susceptibility test was performed with VITEK $2^{\circledast}$ automated system (Biomérieux, France) and was evaluated according to the Clinical and Laboratory Standards Institute 2017 guideline ${ }^{[5]}$.

Since the isolated strain was found to be resistant to ciprofloxacin and susceptible to amoxicillin/clavulanate and clindamycin, the patient was treated with a combination of amoxicillin/clavulanate $3 \times 1 \mathrm{gr}$ po and clindamycin 3x600 mg po for three weeks. At the end of the treatment, all lesions and complaints disappeared, and the patient was free of complaints in the $10^{\text {th }}$ month of follow-up.

\section{Discussion}

Corynebacterium amycolatum is an aerobic or facultatively anaerobic, non-spore-forming Gram-positive bacillus and is one of the few Corynebacterium species that does not contain mycolic acid in its cell wall[6]. It was first isolated from clinical specimens in 1988 and was shown to be distantly related to other Corynebacterium species ${ }^{[7]}$. C. amycolatum has been isolated from clinical specimens such as wound infections, pilonidal sinus, mastitis, endocarditis, and septic arthritis ${ }^{[7,8]}$.

Corynebacterium amycolatum-associated breast infections have been reported rarely ${ }^{[9,10]}$. This is because diphtheroids are members of the skin and mucosal microbiota and their identification is difficult.

The development of new technologies such as 16S RNA sequencing and MALDI-TOF MS have enabled clinical microbiology laboratories to identify many microorganisms up to genus and species level in a short time. In the patient we followed up, the causative agent $C$. amycolatum was identified with MALDI-TOF MS in a short time and was successfully treated with a combination of antibiotics.

Although Staphylococcus aureus ranks first among the infectious agents of mastitis, it should not be forgotten that Corynebacterium species may also be causative agents. In New Zealand, Paviour et al. ${ }^{[11]}$ reported that Corynebacterium species were one of the factors that should be kept in mind among mastitis agents in a cohort study of 24 female patients with mastitis. They reported that $C$. kroppenstedtii, C. amycolatum and $C$. tuberculostearicum were the most frequently reproduced species.

In another study reported from South India, it was shown that $C$. amycolatum/C. xerosis was isolated in 5 samples, $C$. kroppenstedtii in 4 samples, and $C$. striatum in 1 sample, taken from 10 patients with mastitis ${ }^{[12]}$. In addition, the examination of antibiotic susceptibility of isolated species reflects the importance of antibiogram in the treatment approach of mastitis caused by Corynebacterium species $^{[13,14]}$.

In patients with mastitis, taking cultures and detecting the causative agent are of great importance in the treatment. Mass spectrometry is the method that is frequently used today to define the types of the determined agent after this stage. There are studies showing that MALDI-TOF MS is the most powerful method in terms of supporting the diagnosis 
of Corynebacterium infections and its suitability for use in the clinical laboratory ${ }^{[15,16]}$.

It is also noteworthy that patients with mastitis in whom Corynebacterium species are produced as a factor are diagnosed as having GM. In this regard, some studies supporting that GM may be associated with Corynebacterium infections are also included in the literature ${ }^{[17,18]}$.

Although there was no guide on treatment and its duration in mastitis caused by Corynebacterium published in the literature; monotherapy or combined antibiotic protocols were used in case series ${ }^{[4]}$.

Although $\beta$-lactam and quinolones are widely used in the empirical treatment of mastitis, it has been reported that their effects in the treatment of Corynebacterium bacteria are weak. Therefore, from New Zealand, Dobinson et al. ${ }^{[4]}$ examined patients with C. kroppenstedtii, C. tuberculostearicum, C. glucuronolyticum, and C. freneyi-induced GM between 2002 and 2013, and they reported that these microorganisms should be treated by evaluating their lipophilicity and antibiotic susceptibility, but also they supported the use of clarithomycin and rifampicin, which were also used in the treatment of other granulomatous diseases.

Short-term antimicrobial therapy is not evaluated in favor of positive clinical results, and it is stated that the literature on treatment duration is limited ${ }^{[4]}$. The patient's unresponsiveness to this treatment which was empirically initiated, could be explained by the low lipid solubility of fluoroquinolones and the lipophilic nature of $C$. amycolatum isolated from the patient. Therefore, low lipid solubility $\beta$-lactam and quinolones will be less effective in cases of GM caused by lipophilic Corynebacterium. The patient was treated for three weeks with a combination of amoxicillin/clavulanate $3 \times 1 \mathrm{gr}$ po and clindamycin $3 \times 600$ $\mathrm{mg}$ po, since there was no published protocol in the literature regarding the superiority of monotherapy or dual therapy over each other and $C$. amycolatum isolated from the culture taken from the patient was found to be resistant to ciprofloxacin and sensitive to amoxicillin/clavulanate and clindamycin. Since it was reported that short-term treatments resulted in clinical failure, the duration of treatment was extended to three weeks ${ }^{[4]}$.

\section{Conclusion}

The aim of this case report was to emphasize the importance of taking samples for culture from patients with suspected or confirmed mastitis and the importance of culture-grown Corynebacterium bacteria as the causative agent of mastitis. MALDI-TOF MS can be of great help in the effective treatment of patients with mastitis due to its rapid identification ability. With effective treatments, such conditions, which are extremely problematic for patients, can be treated in a short time.

\section{Ethics}

Informed Consent: Verbal consent was obtained from the patient.

Peer-review: Externally and internally peer-reviewed.

\section{Authorship Contributions}

Surgical and Medical Practices: Z.B., M.Y., Data Collection or Processing: N.B.K., Writing: Z.B., M.Y.

Conflict of Interest: No conflict of interest was declared by the authors.

Financial Disclosure: The authors declared that this study received no financial support.

\section{References}

1. Kessler E, Wolloch Y. Granulomatous mastitis: a lesion clinically simulating carcinoma. Am J Clin Pathol. 1972;58:642-6.

2. Barreto DS, Sedgwick EL, Nagi CS, Benveniste AP. Granulomatous mastitis: etiology, imaging, pathology, treatment, and clinical findings. Breast Cancer Res Treat. 2018;171:527-34.

3. Bakaris $S$, Yuksel $M$, Ciragil $P$, Guven MA, Ezberci $F$, Bulbuloglu E. Granulomatous mastitis including breast tuberculosis and idiopathic lobular granulomatous mastitis. Can J Surg. 2006;49:427-30.

4. Dobinson HC, Anderson TP, Chambers ST, Doogue MP, Seaward L, Werno AM. Antimicrobial Treatment Options for Granulomatous Mastitis Caused by Corynebacterium Species. J Clin Microbiol. 2015;53:2895-9.

5. Clinical and Laboratory Standards Institute. Performance standards for antimicrobial susceptibility testing. $27^{\text {th }} \mathrm{ed}$. CLSI supplement M100. Wayne, PA: Clinical and Laboratory Standards Institute; 2017.

6. Reddy BS, Chaudhury A, Kalawat U, Jayaprada R, Reddy G, Ramana BV. Isolation, speciation, and antibiogram of clinically relevant non-diphtherial Corynebacteria (Diphtheroids). Indian J Med Microbiol. 2012;30:52-7.

7. Soltan Mohammadi N, Mafakheri S, Abdali N, Barcena-Uribarri I, Tauch A Benz R. Identification and characterization of the channel-forming protein in the cell wall of Corynebacterium amycolatum. Biochim Biophys Acta. 2013;1828:2574-82.

8. Kazmierczak AK, Szarapinska-Kwaszewska JK, Szewczyk EM. Opportunistic coryneform organisms--residents of human skin. Pol J Microbiol. 2005;54:27-35.

9. Butta H, Pasha F, Dawar R, Kashyap V, Mendiratta L, Bora U, Sardana R. Corynebacterium amycolatum causing breast abscess: An infecting Diphtheroid with a difference. Ann Pathol Lab Med. 2017:4:C128-30.

10. Ozaydin I, Yildirim M, Sahin I, Dogan S. Recurrent breast abscess caused by Corynebacterium amycolatum: A case report. Turk J Med Sci. 2009;39:1479.

11. Paviour S, Musaad S, Roberts S, Taylor G, Taylor S, Shore K, Lang S, Holland D. Corynebacterium species isolated from patients with mastitis. Clin Infect Dis. 2002;35:1434-40.

12. Poojary I, Kurian A, V AJ, Devapriya JD, M AT. Corynebacterium species causing breast abscesses among patients attending a tertiary care hospital in Chennai, South India. Infect Dis (Lond). 2017;49:528-31.

13. Neemuchwala A, Soares D, Ravirajan V, Marchand-Austin A, Kus JV Patel SN. In Vitro Antibiotic Susceptibility Pattern of Non-diphtheriae 
Corynebacterium Isolates in Ontario, Canada, from 2011 to 2016. Antimicrob Agents Chemother. 2018;62:e01776-17.

14. Zalas P, Mikucka A, Gospodarek E. [Antibiotic sensitivity of Corynebacterium amycolatum]. Med Dosw Mikrobiol. 2004;56:327-34.

15. Bao R, Gao X, Hu B, Zhou Z. Matrix-assisted laser desorption ionization time-of-flight mass spectrometry: a powerful tool for identification of Corynebacterium species. J Thorac Dis. 2017;9:3239-45.

16. Alibi S, Ferjani A, Gaillot O, Marzouk M, Courcol R, Boukadida J. Identification of clinically relevant Corynebacterium strains by Api Coryne,
MALDI-TOF-mass spectrometry and molecular approaches. Pathol Biol (Paris). 2015;63:153-7.

17. Ang LM, Brown H. Corynebacterium accolens isolated from breast abscess: possible association with granulomatous mastitis. J Clin Microbiol. 2007;45:1666-8.

18. Taylor GB, Paviour SD, Musaad S, Jones WO, Holland DJ. A clinicopathological review of 34 cases of inflammatory breast disease showing an association between Corynebacteria infection and granulomatous mastitis. Pathology. 2003;35:109-19. 